Please cite this article as:

Abecassis-Moedas C, Mahmoud-Jouini SB, Dell'Era C, Manceau D and Verganti R (2012).

Key resources and internationalization modes of creative knowledge-intensive business services: the case of design consultancies.

Creativity and Innovation Management, Vol. 21, No.3, Pp. 315-331. (DOI: $10.1111 / \mathrm{j} .1467-8691.2012 .00646 . x)$ 


\section{KEY RESOURCES AND INTERNATIONALIZATION MODES OF CREATIVE KNOWLEDGE-INTENSIVE BUSINESS SERVICES: THE CASE OF DESIGN CONSULTANCIES ${ }^{1}$}

Special Issue "International Product Development Management Conference" (Delft)

\section{Celine Abecassis-Moedas}

Universidade Católica Portuguesa

Palma de Cima, 1649-023 Lisboa, Portugal

Email: ceabec@clsbe.lisboa.ucp.pt

\section{Sihem Ben Mahmoud-Jouini}

HEC Paris

1, rue de la Libération, 78351 Jouy en Josas Cedex, France

Email: jouini@hec.fr

Claudio Dell'Era (corresponding author)

Politecnico di Milano, Department of Management, Economics and Industrial Engineering Piazza L. da Vinci 32 - 20133 Milano, Italy

E-mail: claudio.dellera@polimi.it

\section{Delphine Manceau}

ESCP Europe

79, avenue de la Republique, 75011 Paris, France

Email: manceau@escpeurope.eu

\section{Roberto Verganti}

Politecnico di Milano, Department of Management, Economics and Industrial Engineering Piazza L. da Vinci 32 - 20133 Milano, Italy

E-mail: roberto.verganti@polimi.it

\section{ACKNOWLEDGMENTS}

The authors would like to acknowledge all the practitioners who collaborated with us during the in-field data gathering process. The authors would like as well to thank the chair of entrepreneurship of the Chamber of Commerce of Paris (CCIP) and the Chamber of

\footnotetext{
${ }^{1}$ Authors are listed alphabetically, not in order of importance.
} 
Commerce of Milan (CCIAA) that both supported this research. The author acknowledges the support of FCT's grant CMU-PT/Etech/0036/2008. Financial support from the Lombardy Region fund "Dote Ricercatori e della Dote Ricerca Applicata per lo sviluppo del capitale umano nel sistema universitario lombardo" is also gratefully acknowledged. 


\title{
KEY RESOURCES AND INTERNATIONALIZATION MODES OF CREATIVE KNOWLEDGE-INTENSIVE BUSINESS SERVICES: THE CASE OF DESIGN CONSULTANCIES
}

\begin{abstract}
In the "knowledge economy", knowledge-intensive business services (KIBS) are a key driver for innovation and competitiveness. The internationalization of these businesses raises challenges given their specificities such as knowledge intensity, the importance of customer interaction and of intimacy in service delivery. This paper focuses on design consultancies as a specific type of creative KIBS for which these characteristics are emphasized, considering the importance of individual and collective creativity and understanding the local context. The objective of this research is to analyze the resources leveraged by the firms to compete internationally. It is based on 11 case studies of Design Consultancies located in 5 different countries (France, Italy, Portugal, Spain and the United Kingdom) that were selected for their capacity to perform at the international level for several years. The paper advances three internationalization modes depending on contingent variables and focusing on specific resources that enable international competitiveness: Star-based, Process-based and Glocalitybased. In Star-based Creative KIBS, the individual designer has developed a reputation that attracts customers internationally, operating as a brand. In Process-based Creative KIBS, the reputation of a collective creative process attracts clients from other countries. In Glocalitybased Creative KIBS, the geographical proximity obtained by opening international offices helps to develop a close understanding of the client through frequent interactions, and also to know the client's market well and to better understand local codes and signs. These modes complement those presented in the existing internationalization literature which takes the peculiarities of creative KIBS into consideration.
\end{abstract}




\section{INTRODUCTION}

In the "knowledge economy" promoted by the European Lisbon strategy, knowledgeintensive services appear as a key driver for innovation and competitiveness. In particular, knowledge-intensive business services (KIBS) are considered to be "bridges of innovation" (Czarnitzki and Spielkamp, 2000). KIBS providers "rely on professional knowledge or expertise relating to a specific technical or functional domain" (Windrum and Tomlinson, 1999). KIBS include a wide range of services, e.g. banking and financial, legal, accounting, marketing, advertising, human resource management and design consultancies (Katsoulacos and Tsounis, 2000). While the international development of manufacturing activities is often based on economies of scale, KIBS need alternative paths because of their knowledge intensity and the importance of strong and close relationships with the client. This is heightened in the case of creative KIBS such as architecture, advertising, web services, branding or design agencies which are based on creative processes and individuals, thus reducing economies of scale even further. Internationalization is becoming a major challenge for creative KIBS companies which in the past were small and operated locally, whereas today the markets for creative services are becoming global. The importance of this phenomenon is growing significantly in terms of both demand and service offering: clients are starting to buy creative services from foreign consultancies, and a few creative KIBS are starting to operate globally. Most of them are still stuck in the old "small and local" model, based on local demand and local service offering, but a few creative KIBS have already experimented with a "large and global" perspective.

In this context, this paper analyzes the key resources that creative KIBS companies leverage to grow internationally and the internationalization modes that they adopt to do so. To address this issue, we chose to study design consultancies (DC) as typical examples of creative KIBS (Muller, 2001). Design consultancies are situated at the intersection between KIBS and creative industries. They are professional, applied creative services (Hill \& Johnson, 2003) where creativity is not employed for its own sake but rather towards the achievement of some other purpose. We will focus on three characteristics specifically relevant to the internationalization process. First, the geographical proximity between design consultancies and their clients. In this industry, projects are based on frequent and numerous meetings during which design consultancies and their clients share different pieces of knowledge in order to conceive new scenarios and concepts (Colombo et al., 2011). Second, design consultancies have been depicted as "knowledge brokers" (Hargadon, 2003; Sutton, 2002), that is, "firms that span multiple markets and technology domains and innovate by brokering knowledge from where it is known to where it is not" (Hargadon, 1998 pp. 210). Hence, knowledge, either individual or collective, is their main asset. Third, according to Verganti (2006), "design deals with the meanings that people give to products". Consequently, knowledge of socio-cultural trends and their impact on the interpretation of product meanings is paramount and means that companies must access tacit and distributed knowledge concerning patterns of consumption, behaviors, and the values of the society.

These characteristics highlight the fact that design consultancies have to face crucial challenges to be competitive at the international level, in addition to the diseconomies of scale they face. We argue that creative KIBS have specific modes of internationalization that are compatible with these specificities: knowledge-intensity; individual and collective creative 
processes; strong client relationships and local embeddedness (Muller and Zenker, 2001). The paper employs a qualitative methodology using 11 case studies of design consultancies from different European countries (Italy, France, Spain, Portugal, and the UK). The selected design agencies have been operating at the international level for many years, but have different profiles in terms of size, organization and international modes. Based on these case studies, we identify three alternative modes for internationalization: Star-based, Process-based and Glocality-based. Each mode is characterized and discussed, in the light of the specificities of creative KIBS and the literature on internationalization.

The paper is organized as follows: the next section analyzes the theoretical background of KIBS, key resources for internationalization and presents our research objectives. Our methodology is described in the third section and data are analyzed in the fourth. The fifth section discusses the different modes for the internalization of creative KIBS. Finally, conclusions are presented and avenues for future research are outlined.

\section{THEORETICAL BACKGROUND AND RESEARCH OBJECTIVES}

In order to explore key assets and modes that creative KIBS can adopt in order to grow internationally, we draw on two different literature streams: first we introduce the specificities of KIBS focusing on design consultancies, then we discuss key resources that support international competitiveness drawing on the internationalization literature. Finally, we detail our research objectives.

\section{The specificities of creative KIBS such as design consultancies}

Service sectors are expanding in all advanced industrial economies, driven by the rapid growth of their most knowledge-intensive segments (NSF, 2010). Over the last decades, the development of industrialized countries has been characterized by the strong diffusion of KIBS (Hipp, 2000; Muller, 2001; Miles, 2007; Oke, 2007). According to Windrum and Tomlinson (1999), "KIBS are services that rely on professional knowledge or expertise relating to a specific technical or functional domain". Doloureux and Muller (2007) claim that the perception of KIBS has evolved from an early characterization as providers of specific information for their clients (Wood et al., 1993) to the recent identification as key nodes of knowledge-related networks, which can trigger and reinforce processes of knowledge conversion in client firms (den Hertog, 2000). The importance of KIBS is growing especially in those countries where manufacturing competitiveness significantly depends on knowledge content provided by highly specialized suppliers such as KIBS providers. In fact, KIBS providers can be interpreted as primary sources for innovation. Several researchers emphasize the fresh ideas provided by these "bridges of innovation" in advanced economies, which interact with the manufacturing sector as knowledge purchasers, providers and partners (Czarnitzki and Spielkamp, 2000).

Knowledge lies in people and in organizations. Given the intensity of knowledge and the simultaneity of production and consumption in services, people play a critical role. Some service firms are built around the reputation and the value of their founder; so much so that the company may even be named after the founder(s) (e.g. McKinsey, Ernst \& Young). In this perspective, KIBS aggressively tap the job market in order to hire new talents and to exploit capabilities and competences developed by experts. At the same time they need to formalize 
and codify the knowledge within the organization to transform it into organizational routines and culture. The development of methodologies and case histories aims at transferring tacit knowledge and experiences in order to be useful and effective in delivering services to new clients. During service delivery, processes not only need large flows of codified technical information, but also tacit knowledge that can be used to build trust and to provide interpretative tools. Proximity matters (Koschatzky and Zenker, 1999) because clients and providers have intensive and tacit interaction. Services are characterized by a higher degree of customization compared to goods; for this reason, the provider-client interaction and spatial proximity take on greater importance.

We will focus on one specific type of KIBS: the creative KIBS based on creative processes and individuals where creativity is not employed for its own sake but rather for the achievement of some other purpose. In these types of service, creativity could be expected in a form that is much more explicit and central to the offering than in other KIBS such as management consulting or accounting. We will look more specifically at design consultancies that play a critical role in new product development (NPD) processes (Hargadon and Sutton, 1997; Hargadon, 1998; Chiaroni et al., 2008; Abecassis-Moedas and Ben Mahmoud Jouini, 2008; Colombo et al., 2011; Colombo et al., 2012). Design is a key activity for the innovation process (Ulrich and Eppinger, 2011; Dell'Era et al., 2011). It offers an effective way to strategically differentiate and position products (Ravasi and Lojacono, 2005; Verganti, 2006; Dell'Era and Verganti, 2007; Verganti, 2009; Dell'Era and Verganti, 2010). Rindova and Petkova (2007) argue that product-form design decisions have implications for the strategic positioning of the firm and its products. Thus, design plays a crucial role in the differentiation of the products through symbolic and aesthetic dimensions and as such represents a critical competitive advantage and innovation driver.

Hill and Johnson (2003) point out that applied creative services, and especially design, require a very high level of customization. Considering the five-phase process of creativity suggested by Amabile (1988), they show that the customer plays a significant role in the service process: four of the five phases involve close interactions between the customer and the creative supplier. Only one phase is the preserve of the creative professional. A second specificity of these services is that they are people-based rather than equipment-based services (Hill and Johnson; 2003). Indeed, advertising, architecture, branding and design consultancies rely mainly on human and organizational resources to deliver their services. As in several creative industries, creative individuals play a critical role and their motivations and characteristics, such as their lifestyle, have a great impact on the firm and its operation (Paige and Littrel, 2002). Operating simultaneously alongside creative individuals, in some firms there are collective creative processes. KIBS acquire knowledge from their clients, which allows them in turn to offer client-specific solutions and also to enhance their own knowledge base. According to Hargadon (1999), the combination of this knowledge plays a central role in organizational creativity and innovation: diverse ideas can generate new and valuable combinations through the project team's interactions. Group interactions elicit relevant (and often non-obvious) knowledge from individuals regarding the current situation or past experiences and generate creative ways of combining those ideas to solve new problems. Hargadon and Bechky (2006) introduce a model of collective creativity that explains how the locus of creative problem solving shifts, at times, from the individual to the interactions of a group. According to Verganti (2006), design consultancies need to develop in-depth knowledge of socio-cultural trends in order to anticipate customers' perception of their meaning. This knowledge is tacit, distributed and very diverse: it encompasses patterns of consumption, behaviors and the society's values. 


\section{Key resources for the internationalization of Knowledge-Intensive Business Services}

The literature on internationalization can be divided into two traditional categories: foreign direct investment (by several means, such as launching local businesses or acquiring them) and exports (Sondheimer and Bargas, 1993). Like other categories of services, the foreign direct investment mechanism can be considered dominant in the case of KIBS because of the close interaction between client and provider (Roberts, 1998). A third model was identified through extensive research on the internationalization of services: a foreign presence through third parties. According to Toivonen et al. (2009), international operations through third parties may take the form of franchising, licensing or other collaborative arrangements. Collaborations may be implemented in different configurations that range from non-equity cooperation (network, affiliates, etc) to contracts that include limited ownership. It may include a shared brand, it may involve shared acquisition of contacts and deeper forms of cooperation, like strategic alliances, are also possible. This model provides better control over service delivery and quality, and requires fewer resources than foreign direct investment (Vandermerwe and Chadwick, 1989). For this reason, it seems particularly beneficial for small and medium enterprises (SMEs) as they face considerable barriers when attempting to engage in foreign direct investment compared to large firms (Buckley et al., 1988; Acs et al., 1997; Eden et al., 1997).

Gemser et al. (2004) demonstrate that the cooperative strategy is the preferred internationalization strategy for SMEs. Comparing two sets of companies that operate in different industries, they show that mechanical engineering firms opt for the cooperative strategy due to resource constraints that inhibit a go-it-alone strategy, while software firms (belonging to the KIBS category) adopt the same strategy for capability development and the generation and realization of future value. Kirby and Kaiser (2003) demonstrate that joint ventures can be a successful market-entry strategy, particularly for companies with limited resources and knowledge of the local market. They show that partnership arrangements can be considered the optimal solution not only when government regulations preclude exporting or wholly foreign-owned enterprises. While the traditional view of the internationalization of services predicts that service firms will either follow their clients to foreign markets or follow a gradual path in the case of independent internationalization (Roberts, 1998), recent studies show that service providers may also internationalize very rapidly and that some of them are even "born global" (Chetty and Campbell-Hunt, 2004). Toivonen (2004) points out that KIBS can go international through clients: either by serving foreign clients in their home country or by serving internationally operating domestic clients.

\section{Research objectives}

The literature on internationalization focuses mainly on market access (direct or indirect) rather than on the resources required. We find that this focus does not help to understand the modes of internationalization used by KIBS, and specifically creative KIBS, because it does not take their specificities into consideration. The need for in-depth knowledge of local cultural, regulatory and organizational issues and face-to-face interaction between supplier and client can make internationalization difficult (Toivonen, 2004; Miles, 2005; Corrocher et al., 2009). Unlike manufacturing sectors where there is a long-term tendency for larger firms to emerge and develop, most KIBS sectors are not highly concentrated. Very often small firms operating in regional or specialized niches collaborate with a small number of very large firms operating transnationally. While some KIBS sectors such as computer services and auditing services manifest clear concentration phenomena, others such as design 
consultancies are characterized by small and micro businesses. However, some DC are competitive at the international level.

Our research objective is to analyze the key resources on which creative KIBS and especially DC that are competitive at the international level base their internationalization. The paper investigates their approaches to creating and transferring knowledge, taking into account their specificities as KIBS (Muller and Zenker, 2001) and as applied creative services (Hill and Johnson, 2003): knowledge-intensity, individual and collective creative processes, local embeddedness and strong client relationships.

\section{METHODOLOGY}

There is little research on creative KIBS. To analyze them, we chose one type of creative KIBS: design consultancies (hereafter DC). The research methodology is based on detailed case studies of DC. The case studies were selected based on survival and competitiveness in an international context: specifically, we selected only DC that have been competing at the international level for more than 3 years and show percentages of turnover from international projects higher than $10 \%$. As mentioned in the introduction, only a few creative KIBS have already started a globalization process. The sample is made up of $11 \mathrm{DC}$ originating from 5 countries (see Table 1): France (3), Italy (4), Iberia (Spain \& Portugal) (2), and the UK (2). The sample was composed of survivors, therefore by research design there is a survivor bias. The objective is not to identify the paths through which creative KIBS go international, but the different existing modes of internationalization. In other words, companies belonging to the sample show, to some extent, successful internationalization modes allowing us to identify interesting relationships among contingent variables, internationalization modes and managerial implications. For this reason, the sample is particularly consistent with the research objectives. The design of the study does not allow us to obtain insights about what leads to failure; this is a research limitation which could be addressed in the future (see Figure $1)$.

\section{Figure 1: Research framework}

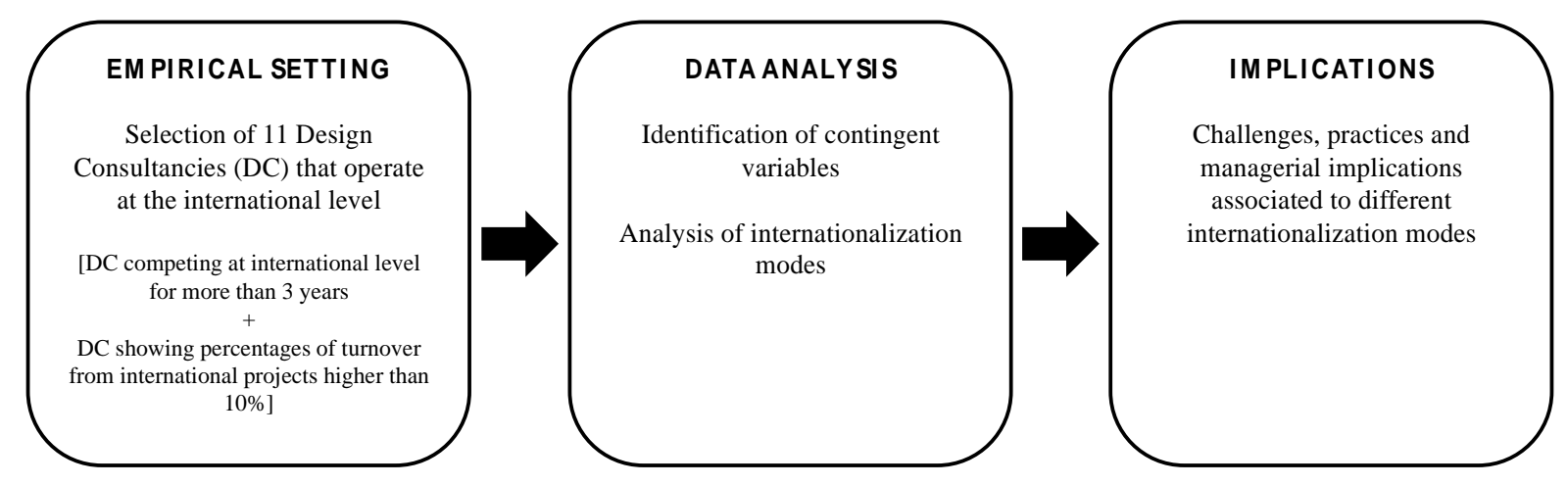

The data were collected through face-to-face interviews following a semi-structured interview guide. The guide was based on a resource-based view approach: it targets the 
identification of resource types in order to understand the creative process and the relationship with clients. Each interview lasted between 1.5 and 2 hours. All the interviews were taped and transcribed. In each firm, the founder or the CEO (often the same person) was interviewed by at least two of the researchers. This gave us access to the most knowledgeable person in the firm. The interview took place at the firm and often a quick tour was given to the researchers. In total, the data set represents over 20 hours of interviews and 200 pages of transcript. Most of the data was collected during the interview. Whenever possible (if the data was available), it was checked or triangulated with publicly available sources (website, press articles, etc.). It is important to remember that the sample is DC, which are small design firms on which there is not much public information. For instance, the proportion of turnover from international activities is based on the interviews and checked using available data.

The data analysis was based on the interview transcripts. Each case was analyzed by at least two researchers. The transcripts were analyzed regarding factual elements that would allow for comparison between cases (see details in Table 2) like foundation year, year of the first international project, number of employees, location of international activity, types of services offered and proportion of staff and turnover from international projects. The next step was the construction of a data matrix (cases / dimensions) as recommended by Miles and Huberman (1994). The transcripts and the matrix (across cases) were analyzed iteratively and separately by the authors. We looked for and found regularities and patterns across cases. The first question was whether or not the company had an international office. For those that did not have an international office, we analyzed the transcript to understand how international clients were reached and how international projects were managed. The analysis of the acrosscase matrix served to identify patterns that gave birth to a typology of creative KIBS internationalization modes and also to associate key resources with each one. This analysis was done iteratively by multiple researchers. 
Table 1: Description of the Creative KIBS

\begin{tabular}{|c|c|c|c|}
\hline Firm & $\begin{array}{l}\text { Country of } \\
\text { origin }\end{array}$ & $\begin{array}{l}\text { Foundation } \\
\text { year }\end{array}$ & Description \\
\hline Dragon Rouge & France & 1984 & $\begin{array}{l}\text { The largest design agency in France and among the five largest design agencies in the world, Dragon Rouge develops a } \\
\text { large range of design activities including packaging, visual identity, interior design and structural design. Its orientation is to } \\
\text { "give brands the power to create change" through a design activity oriented towards consulting. Its clients include well- } \\
\text { known brands and companies such as Danone, Perrier, Colgate, Palmolive, Carte Noire, Marriott, The Laughing Cow, } \\
\text { Whirlpool, Gap and Nestle. }\end{array}$ \\
\hline Massaud & France & 1996 & $\begin{array}{l}\text { The agency created by Jean-Marie Massaud covers a large range of design fields from furniture to industrial products, } \\
\text { equipment and architecture. He collaborates with several brands like B\&B Italia, Axor Hansgrohe, Lancôme and Renault. } \\
\text { His projects include furniture for Cappellini and Cassina, products for Lanvin and Yamaha Offshore and architectural } \\
\text { projects such as the Volcano Chivas stadium in Guadalajara and the Life Reef condominium towers. }\end{array}$ \\
\hline MBD & France & 1972 & $\begin{array}{l}\text { MBD Design develops global design solutions offering its expertise in three main areas: transport design, product design } \\
\text { and graphic design. It is ranked among the international leaders in transport design with clients such as Bombardier, } \\
\text { Siemens, Alstom and the French national rail company (SNCF). The team is expert at managing complex, strategic and } \\
\text { internationally dimensioned projects. }\end{array}$ \\
\hline $\begin{array}{l}\text { Design } \\
\text { Innovation }\end{array}$ & Italy & 1997 & $\begin{array}{l}\text { Established and directed by Carmelo Di Bartolo and Pino Molina Betancor, this agency applies the experience acquired } \\
\text { over more than twenty years of coordinating the requirements of design, production, training, communications and the } \\
\text { market for industry and public administrations. Design Innovation works by setting up interdisciplinary groups where } \\
\text { designers, architects, engineers, economists and experts in the construction of consumption scenarios and models team up } \\
\text { with managers, corporate executives and technicians to develop future scenarios and designs. }\end{array}$ \\
\hline $\begin{array}{l}\text { Design Group } \\
\text { Italia }\end{array}$ & Italy & 1968 & $\begin{array}{l}\text { Founded by Marco Del Corno, Design Group Italia is managed by } 4 \text { partners: Edgardo Angelini, Ross De Salvo, Peter } \\
\text { Newbould, Sigurdur Thorsteinsson. The quality of Design Group Italia's contribution to every stage is based on the ability } \\
\text { to bring marketing, communication and technological considerations together to form a good idea. Design Group Italia has } \\
\text { gained a lot of experience and knowledge in understanding emerging consumer trends and styles across diverse market } \\
\text { sectors. }\end{array}$ \\
\hline $\begin{array}{l}\text { Antonio } \\
\text { Citterio and } \\
\text { Partners }\end{array}$ & Italy & 1999 & $\begin{array}{l}\text { Founded by Antonio Citterio and Patricial Viel. Antonio Citterio opened his studio in } 1972 \text { where he started his } \\
\text { architectural and interior design business. Between } 1987 \text { and } 1996 \text { he worked in association with Terry Dwan and, together, } \\
\text { they created buildings in Europe and Japan. Among his most significant works: the restyling of a block in the historical } \\
\text { centre of Seregno, Esprit headquarters in Amsterdam, Antwerp and Milan, industrial plants for Vitra, in Germany and for } \\
\text { Antonio Fusco in Milan. }\end{array}$ \\
\hline $\begin{array}{l}\text { Studio Marco } \\
\text { Piva }\end{array}$ & Italy & 1984 & $\begin{array}{l}\text { Marco Piva is an Italian architect and designer. Studio Marco Piva has activities ranging from large architectural projects } \\
\text { for tourist facilities, to interior design and finally industrial design for the production of accessories for common areas. In } \\
\text { 1987, Marco Piva also founded IDA, International Design Agency, an Italian interface for a World Design Network system. } \\
\text { In 2001, a variety of experiences in strategic consulting in the field of design and hotel contract work culminated in } \\
\text { consulting work with the contract division of Federlegno - Arredo. }\end{array}$ \\
\hline
\end{tabular}




\begin{tabular}{|l|l|l|l|}
\hline P-06 & Portugal & 2006 & $\begin{array}{l}\text { Founded by 4 people: Nuno Gusmão (architect and painter), his wife Estela (designer), Catarina (economist) and Pedro } \\
\text { (artist). Specialized in environment design (interior, exhibition, signage...). They designed the interior of the Orient } \\
\text { Museum and the Poitiers Museum in France. }\end{array}$ \\
\hline Mariscal & Spain & 1989 & $\begin{array}{l}\text { Founded by artist and designer Javier Mariscal. He offers a broad range of design services (graphic, branding, } \\
\text { communication, products... and audiovisual). Javier Mariscal is a recognized artist (exhibition at London Design Museum). } \\
\text { He created Cobi, the mascot of 1992 Barcelona Olympic Games. }\end{array}$ \\
\hline JKR & UK & 1990 & $\begin{array}{l}\text { JKR is a large packaging design and branding agency which has been advertising in Advertising Week every single week } \\
\text { for the last 18 years. It was named after the initials of the three founders: Jones, Knowles and Ritchie. It works for well- } \\
\text { known brands of companies such as Unilever, Diageo, United Biscuits, Mars, Silver Spoon and Birdseye. }\end{array}$ \\
\hline Webb de Vlam & UK & 1992 & $\begin{array}{l}\text { Founded by 3 UK designers with previous experience in internal design departments (Electrolux) or in the founding a } \\
\text { previous design agency (sold afterwards), Webb de Vlam is named after the two founders that remain in the company. It } \\
\text { offers packaging and product design services to companies such as P\&G, Gillette, ICI and Bombay Sapphire gin. }\end{array}$ \\
\hline
\end{tabular}




\section{DATA ANALYSIS: KEY RESOURCES DRIVING INTERNATIONAL ACTIVITIES}

We decided to adopt the resource-based view theory as a framework for analyzing the resources that firms depend on to be competitive in an international context. As seen in Table 2 , our case studies show that all firms have a significant international activity (ranging from 10 to $75 \%$ of revenue) and operate in several countries in addition to their domestic locations. It is interesting to note that only two firms (Dragon Rouge and Webb de Vlam) have opened foreign offices to be close to their clients. These offices can be categorized as physical capital. The other firms have based their expansion on other resources. It emerges from the interviews that some firms emphasize the key role played by the individual designer, whereas others point to strong creative processes. These can be categorized as human and organizational capital respectively. From our data analysis, three groups of companies emerge, each of them based on a specific approach (see last column of Table 2).

The first group of design consultancies, which we call Star-based Creative KIBS, is based on the human capital resource: these companies are built on the individual creativity and the reputation of a designer that is internationally recognized. These firms do not require international offices. The collective creative process is weak and client intimacy is built on a personal relationship with the designer. International development is achieved through export or through a third party that facilitates client interaction. For example Massaud and Antonio Citterio are world famous designers: the former has won 15 international prizes and has been appointed "Designer of the Year" several times; the latter has won several "Compasso d'Oro" and "Red dot design" awards which are two of the most prestigious design prizes in the world. Mariscal is both an artist and a designer and some of his work has been exhibited at the London Design Museum. The artist/designer's name is famous worldwide, which makes it possible to reach international clients in various countries.

"Clients are attracted to us because of Mariscal's 'name' [...]. Some clients ask Mariscal to sign the product, but it is not always appropriate. The client should promote his brand, not Mariscal [...]. We have had offers to open offices abroad but we don't want to go that way."

Manager of Mariscal

P-06 is involved in numerous projects abroad, including one where they designed the interior of Poitiers Museum in France. They gain access to these projects through a very famous and recognized Portuguese architect (Carrilho da Graça). When the architect wins international competitions, the interior design is done by P-06.

"With Carrilho de Graça, we bid on international architecture calls. He is one of the very famous architects involved in international projects and we go along for the international design part. We recently did the Poitiers Museum".

CEO and founder of P-06 
Studio Marco Piva has developed specific competences and reputation in the management of big architectural projects. Given the magnitude of this category of projects, Studio Marco Piva has built a series of partnerships with engineering companies and architectural studios around the world. Specifically, these collaborations are based on complementary competences that Studio Marco Piva and other studios can provide. This internationalization mode based on achieving an international presence through third parties allows them to make contact with several clients while avoiding significant investments that would be required by the foreign direct investment approach. Antonio Citterio and Partners also develop internal "explorative" projects. These are not carried out for specific clients, but they improve the proactive attitude of the studio and they allow the founders to disseminate their vision of future scenarios, thus helping them to gain international visibility.

\begin{abstract}
"The studio has developed several projects in foreign countries such as Russia and the United Arab Emirates thanks to the reputation developed during its history. The international prizes received in several competitions, the 'made in Italy' DNA demonstrated by the studio and the capability to harmonize engineering, architectural and managerial skills has enabled it to establish several collaborations with engineering companies and studios that operate at the local level."
\end{abstract}

Manager of Antonio Citterio and Partners

The second group of design consultancies, which we call Process-based Creative KIBS, is based on the organizational capital resource: it is built on the development of collective creative processes and methods. These design consultancies have formalized the different steps of their design projects, have explicitly determined which type of internal competence should be used and combined at each step, and when and how they should interact with the client. Thus, Process-based Creative KIBS are characterized by organized processes, both with the client and internally to generate innovative solutions. Such a process orientation is sometimes enabled by some specialization, either in one type of design activity (packaging and visual design for JKR) or in an industry (transport for MBD and white goods for Design Innovation). In this model, international development is achieved through export. For example, the quality of Design Group Italia's contribution to every stage is based on the ability to bring marketing, communication and technological considerations together to form a good idea. The approach of this design consultancy is based on three main phases:

- Orientation: through an understanding of the competitive landscape, consumer life-styles, and emerging trends, they help their clients draw up a tailor-made roadmap for innovation;

- Creation: production processes that fit the client's means together with the knowledge gained during Orientation create a strong foundation for the exploration of new concepts;

- Implementation: once concepts are to be implemented, Design Group Italia continues to help the design move forward, providing support at both the technical and the brand level, ensuring that an optimum experience is delivered.

"We're not aligned with the typical Italian design model that is built around single personalities. Our model is more Anglo-Saxon. [...] We don't have a house style, so we always devote part of our process to understanding which style best fits a brand, a product, and so on." 
MBD is a French agency specialized in transport design (high speed trains, regional trains, urban trains, locomotives...). They have developed a 4-stage process: (1) familiarization with the client's needs through client meetings, market research and benchmarking, (2) design creation with 3-4 designers on each project doing both individual and collective work under the supervision of a project manager, leading to the client presentation, (3) development of graphic plans and possibly a prototype, maintaining constant interaction with the client, (4) industrialization is carried out by the client but with a designer acting as a regular consultant. The designer teams work on the project throughout all the stages. Also, in the second group of design consultancies, JKR is a leading design company in the UK specialized in consumer goods packaging. They employ more than 95 people and handle 400 projects each year, which are achieved through strong process orientation. "We have a very strict system" says the managing director. The process is formalized and written. Each project leads to the formation of a team of 10 to 20 people, including one or two account managers in charge of the relationship with the client, the correct understanding of the client's brief and the quality of the creative work; 8 to 12 designers including some people specialized in specific aspects of design and a creative director; and people in charge of technical aspects. The executive creative director has 3 creative directors reporting to him and sees every project. This strong process orientation is the reason why they chose not to open offices abroad; they consider it would loosen the consistency of the process and of the work created in the agency.

The third group, which we have named Glocality-based Creative KIBS, is a hybrid and is based on both physical capital, through investment in local offices, and organizational capital, through the implementation of processes developed at the domestic location, such as the client intimacy process. These companies develop direct relationships with clients located in several countries by setting up local offices and use creative processes developed at the domestic location. For example, Webb de Vlam has three offices around the world (in the US and Australia in addition to the original UK office), which allow the company to constantly interact with its customers and to conduct local marketing research to better understand the end consumers that its customers are targeting. The original founders manage each of the local offices, leading to a strong collaboration between the offices and a consistent company culture, described by the CEO as a "family kind of culture". Some projects bring together designers from several offices, favoring a common approach. The main motivation for opening local offices is to be close the clients so as to interact with them a great deal and to better understand their market through local embeddedness and market research. Dragon Rouge, a large design agency with 320 employees, has offices in several countries outside of France: the UK, Germany, Poland, Dubai, the US and China.

\begin{abstract}
"We chose to develop internationally by opening local offices [...]. I do not think we are in a global activity because the cultural aspect is still very important. It is a multi-local activity and each local office has strong local embeddedness. There are still many companies, many brands, that have a local marketing strategy and you need people that understand the local consumer and the local cultural codes and signs. To run our local offices, we hire people with an entrepreneurial motivation who are locals or who have lived in the country for many years. And then we coach them."
\end{abstract}

Manager of Dragon Rouge 
Glocality-based Creative KIBS are able to intercept and then interpret specific trends and needs coming from different territories and then provide customized solutions that embed cultural specificities. Given that communicative codes differ significantly from one country to another, this mode is particularly useful for those creative KIBS that provide services relating to brand and visual identity to food and FMCG (Fast Moving Consumer Goods) companies that have local brands and products. Some differences in company characteristics have been identified between the three groups: it seems that the type of service provided by the DC in each of the groups is different. The star-based group appears to be more involved in architecture and product design, the process-based group more in packaging and the glocalitybased group more in brands and a broad range of activities. 
Table 2: International activities developed by the Creative KIBS

\begin{tabular}{|c|c|c|c|c|c|c|c|c|}
\hline Design Consultancy & $\begin{array}{l}\text { Founda- } \\
\text { tion year }\end{array}$ & $\begin{array}{l}\text { Year of } \\
\text { first } \\
\text { interna- } \\
\text { tional } \\
\text { project }\end{array}$ & $\begin{array}{l}\text { Number of } \\
\text { employees (2009) }\end{array}$ & $\begin{array}{l}\text { (Domestic location) and } \\
\text { international location }\end{array}$ & Typology of services & $\begin{array}{l}\text { \% staff in } \\
\text { foreign } \\
\text { offices }\end{array}$ & $\begin{array}{l}\% \\
\text { turnover } \\
\text { from } \\
\text { interna- } \\
\text { tional } \\
\text { projects in } \\
2008 \text { and } \\
2009\end{array}$ & $\begin{array}{l}\text { Internatio- } \\
\text { nalization } \\
\text { modes }\end{array}$ \\
\hline $\begin{array}{l}\text { Antonio Citterio } \\
\text { and Partners }\end{array}$ & 1999 & 1999 & $\begin{array}{l}20 \\
+40 \mathrm{PBC}^{*}\end{array}$ & $\begin{array}{l}\text { (Italy), France, Germany, UK, } \\
\text { Russia, Indonesia, USA } \\
\end{array}$ & \begin{tabular}{|l|} 
Architecture \\
Product \\
\end{tabular} & $\begin{array}{l}\text { No foreign } \\
\text { office }\end{array}$ & $50 \%$ & \multirow{5}{*}{$\begin{array}{l}\text { Star- } \\
\text { based } \\
\text { Creative } \\
\text { KIBS }\end{array}$} \\
\hline Studio Marco Piva & 1984 & 1987 & 35 & \begin{tabular}{|l} 
(Italy), Russia, Siberia, \\
United Arab Emirates, Egypt
\end{tabular} & \begin{tabular}{|l|} 
Architecture \\
Product \\
\end{tabular} & $\begin{array}{l}\text { No foreign } \\
\text { office }\end{array}$ & $35 \%$ & \\
\hline P-06 & 2006 & 2007 & 12 & (Portugal), France & \begin{tabular}{|l|} 
Interior design \\
Architecture \\
\end{tabular} & $\begin{array}{l}\text { No foreign } \\
\text { office }\end{array}$ & $10 \%$ & \\
\hline Massaud & 1996 & 1996 & $\begin{array}{l}8 \\
+\mathrm{PBC}^{*}\end{array}$ & (France) Mexico, Italy, Korea & \begin{tabular}{|l|} 
Product \\
Architecture
\end{tabular} & $\begin{array}{l}\text { No foreign } \\
\text { office }\end{array}$ & $70 \%$ & \\
\hline Mariscal & 1989 & 1995 & $\begin{array}{l}30 \\
+ \text { up to } 50 \mathrm{PBC}^{*}\end{array}$ & (Spain), Japan, UK, Chile & \begin{tabular}{|l|} 
Product \\
Brand
\end{tabular} & $\begin{array}{l}\text { No foreign } \\
\text { office }\end{array}$ & $40 \%$ & \\
\hline MBD & 1972 & 2007 & $\begin{array}{l}14 \\
+\mathrm{PBC}^{*}\end{array}$ & $\begin{array}{l}\text { (France), South Korea, China, } \\
\text { Singapore, and Middle East }\end{array}$ & \begin{tabular}{|l|} 
Product \\
Packaging
\end{tabular} & $\begin{array}{l}\text { No foreign } \\
\text { office }\end{array}$ & $50 \%$ & \multirow{4}{*}{$\begin{array}{l}\text { Process- } \\
\text { based } \\
\text { Creative } \\
\text { KIBS }\end{array}$} \\
\hline Design Innovation & 1997 & 2001 & $\begin{array}{l}8 \\
+15 \mathrm{PBC}^{*} \\
\end{array}$ & $\begin{array}{l}\text { (Italy), Spain, Australia, } \\
\text { USA, }\end{array}$ & \begin{tabular}{|l|} 
Product \\
Packaging \\
\end{tabular} & $\begin{array}{l}\text { No foreign } \\
\text { office }\end{array}$ & $15 \%$ & \\
\hline Design Group Italia & 1968 & 1990 & $\begin{array}{l}6 \\
+23 \mathrm{PBC}^{*}\end{array}$ & (Italy), Germany, Iceland & \begin{tabular}{|l|} 
Product \\
Packaging
\end{tabular} & $\begin{array}{l}\text { No foreign } \\
\text { office }\end{array}$ & $55 \%$ & \\
\hline JKR & 1990 & 1998 & 95 & (UK), US, Japan & $\begin{array}{l}\text { Product } \\
\text { Packaging }\end{array}$ & $\begin{array}{l}\text { No foreign } \\
\text { office }\end{array}$ & $20 \%$ & \\
\hline Dragon Rouge & 1984 & 1991 & 320 & $\begin{array}{l}\text { (France), UK, Germany, } \\
\text { Poland, Dubai, US, China }\end{array}$ & $\begin{array}{l}\text { Brand and Product, } \\
\text { Packaging, Interior design }\end{array}$ & $50 \%$ & $45 \%$ & \multirow{2}{*}{$\begin{array}{l}\text { Glocality- } \\
\text { based } \\
\text { Creative } \\
\text { KIBS }\end{array}$} \\
\hline Webb de Vlam & 1992 & 1998 & 63 & (UK), US, Australia & \begin{tabular}{|l|} 
Brand \\
Visual identity
\end{tabular} & $74 \%$ & $75 \%$ & \\
\hline
\end{tabular}

* project-based collaborators 


\section{DISCUSSION: INTERNATIONALIZATION MODES ADOPTED BY CREATIVE KIBS}

The analysis of 11 DC illustrates that creative KIBS can be competitive in an international context through three modes and by leveraging distinct key resources (see Table 3). The three modes are not mutually exclusive, but as the empirical analysis demonstrates, design consultancies tend to adopt one of them as dominant. Furthermore, the success obtained at the international level by design consultancies in our sample shows that firms can survive by leveraging only one mode. Below, each mode will be further characterized and discussed in terms of the specificities of creative KIBS and the internationalization literature. The resource-based view theory suggests that companies can gain sustainable competitive advantage through different types of resources such as brand names, in-house knowledge, skilled personnel, trade contacts, machinery, efficient procedures, etc (Wernerfelt; 1984). Barney (1991) classifies these resources in three main categories: physical capital resources including plant and equipment used in a firm, its geographical location and its access to raw materials; human capital resources including experience, training, relationships and organizational capital resources including formal and informal planning, control and coordination systems. These three types of resources interact with the specificities of KIBS as highlighted above.

Table 3: Internationalization modes adopted by Creative KIBS

\begin{tabular}{|l|l|l|l|}
\hline $\begin{array}{l}\text { Internationalization } \\
\text { modes }\end{array}$ & $\begin{array}{l}\text { Star-based } \\
\text { Creative KIBS }\end{array}$ & $\begin{array}{l}\text { Process-based } \\
\text { Creative KIBS }\end{array}$ & $\begin{array}{l}\text { Glocality-based } \\
\text { Creative KIBS }\end{array}$ \\
\hline Contingent variables & $\begin{array}{l}\text { Reputation recognized by } \\
\text { international circles }\end{array}$ & $\begin{array}{l}\text { High appropriability of } \\
\text { the benefits coming from } \\
\text { the creative processes }\end{array}$ & $\begin{array}{l}\text { Several potential clients } \\
\text { located in foreign } \\
\text { markets showing similar } \\
\text { cultural specificities }\end{array}$ \\
\hline $\begin{array}{l}\text { Approaches to } \\
\text { internationalization }\end{array}$ & $\begin{array}{l}\text { Export of the individual } \\
\text { designer's talent }\end{array}$ & $\begin{array}{l}\text { Export of the creative } \\
\text { processes }\end{array}$ & $\begin{array}{l}\text { Foreign office providing } \\
\text { understanding of the } \\
\text { local market }\end{array}$ \\
\hline Key resources & $\begin{array}{l}\text { Human capital: } \\
\text { individual talent }\end{array}$ & $\begin{array}{l}\text { Organizational capital: } \\
\text { collective design } \\
\text { processes }\end{array}$ & $\begin{array}{l}\text { Physical capital and } \\
\text { Organizational capital: } \\
\text { client intimacy processes }\end{array}$ \\
\hline
\end{tabular}

From our data analysis we identify three types of KIBS with distinct resources and different internationalization modes:

- Star-based Creative KIBS. Recent studies have underlined the importance of external designers and some of them are even considered to be "superstars": Jacob Jensen and David Lewis for Bang \& Olufsen, Michael Graves for Target, Philippe Starck for several furniture companies, as well as for Nike and Puma (Gierke, 2002; Durgee, 2006). If their reputation is recognized by international circles thanks to prestigious awards, multinational communities, etc., the individual designer of Star-based Creative KIBS develops a reputation that attracts customers internationally. Hence this individual operates as a brand. The designer is a star who represents the main source of competitive advantage and drives the internationalization and growth of the design agency. In terms of the resource-based view of the firm, this is specific human capital that is valuable, rare, imperfectly imitable and non-substitutable: individual talent. As 
argued by Verganti (2009), the introduction of radical innovations in meanings is frequently associated with individual interpretative capabilities and therefore the identification, selection and employment of valuable interpreters are crucial activities. Star designers who are able to demonstrate their interpretive capabilities become attractive resources for international clients;

- Process-based Creative KIBS. An American design consultancy, IDEO, became famous thanks to its strong and detailed processes especially concerning users' needs. Specifically, they developed ad hoc tools such as "Method Cards: 51 Ways to Inspire Design" to support the interaction with users (Brown, 2008). If the appropriability of benefits coming from collective creative processes is particularly high, their reputation will attract clients from other countries. Here again, reflecting on the resource-based view of the firm, it is mainly about organizational capital that is valuable, rare, imperfectly imitable and non-substitutable. Given that the knowledge necessary to develop new meanings is distributed and mainly tacit (Verganti, 2008), creative processes are mainly aimed at supporting the scenario-building and conceptgeneration phases. While widespread practices about New Product Development processes mainly aim at improving efficiency, reducing time-to-market and costs, creative processes support the interpretation and development of new scenarios;

- Glocality-based Creative KIBS: When several potential clients are located in the same geographical area and show similar characteristics in terms of cultural approach, the geographical proximity obtained by opening international offices enables the design consultancy to develop a close understanding of the client through frequent interactions, and also to know the client's market well and to better understand local codes and signs. The specific resource in this model is a mix of physical and organizational capital created by setting up specific client intimacy processes. Design consultancies support their clients in the proposal of new meanings. Very often their contribution is not only dedicated to the development of a specific product or service, but also to the identification of new scenarios that envision radically new experiences for users and that can affect entire product lines, market positions and brands. As demonstrated by Verganti (2009), the development process of new meanings is based on interpretation rather than optimization. For this reason, the intense relationship between design consultancies and their clients usually starts with a close alignment of strategic visions. Several client intimacy processes aim at supporting this alignment in particular.

As previously mentioned, the literature on KIBS internationalization identifies three types of internationalization mode based on the way in which firms access the market: foreign direct investment, exports and international presence through third parties. Considering the specificities shown by creative KIBS and the empirical results obtained, we propose an alternative typology of internationalization modes to the one advanced by Sondheimer and Bargas (1993) and Vandermerwe and Chadwick (1989). This typology is based on the resources mobilized and the internationalization modes used. In this context, the opening of local offices combined with building client intimacy leads to a better understanding of the needs and structure of the local market and supports strong interaction during service delivery, which guarantees service quality. As creative KIBS cannot significantly leverage economies of scale, the internationalization modes suggest alternative resources that can be leveraged in order to ensure a competitive position in an international context. Furthermore, we build on these modes to highlight different challenges that creative KIBS have to face and practices that they can adopt in order to make optimum use of their key resources. We also identify interesting implications regarding internationalization potentialities and the different 
motivations of customers when they choose different categories of creative KIBS (see Table 4).

Table 4: Managerial implications for Creative KIBS and their clients

\begin{tabular}{|l|l|l|l|}
\hline $\begin{array}{l}\text { Internationalization } \\
\text { modes }\end{array}$ & $\begin{array}{l}\text { Star-based } \\
\text { Creative KIBS }\end{array}$ & $\begin{array}{l}\text { Process-based } \\
\text { Creative KIBS }\end{array}$ & $\begin{array}{l}\text { Glocality-based } \\
\text { Creative KIBS }\end{array}$ \\
\hline $\begin{array}{l}\text { Challenges faced by } \\
\text { Creative KIBS }\end{array}$ & Allocate founders' time \\
creative processes & $\begin{array}{l}\text { Interpret local contexts, } \\
\text { maintain service } \\
\text { consistency in different } \\
\text { offices }\end{array}$ \\
\hline $\begin{array}{l}\text { Practices adopted } \\
\text { by Creative KIBS } \\
\text { to harness key } \\
\text { resources }\end{array}$ & $\begin{array}{l}\text { Show the output: } \\
\text { Exhibitions } \\
\text { Publishing }\end{array}$ & $\begin{array}{l}\text { Embody the processes: } \\
\text { Ad hoc tools } \\
\text { - Process formalization }\end{array}$ & $\begin{array}{l}\text { Imbue design activities } \\
\text { with local stories and } \\
\text { cultural references } \\
\text { Develop knowledge } \\
\text { management systems to } \\
\text { share knowledge across } \\
\text { international offices }\end{array}$ \\
\hline $\begin{array}{l}\text { Internationalization } \\
\text { potential of } \\
\text { Creative KIBS }\end{array}$ & $\begin{array}{l}\text { Fast internationalization, } \\
\text { but with a limited potential } \\
\text { over the long run owing to } \\
\text { the founder's time } \\
\text { constraints }\end{array}$ & $\begin{array}{l}\text { Progressive } \\
\text { internationalization, ability } \\
\text { to secure an international } \\
\text { niche positioning based on } \\
\text { specialization }\end{array}$ & $\begin{array}{l}\text { Slow internationalization } \\
\text { but with a high potential in } \\
\text { the long run }\end{array}$ \\
\hline $\begin{array}{l}\text { Reason why } \\
\text { customers work } \\
\text { with Creative KIBS }\end{array}$ & $\begin{array}{l}\text { Legitimize the innovation } \\
\text { by collaborating with a } \\
\text { well-known partner }\end{array}$ & $\begin{array}{l}\text { Outsource innovation and } \\
\text { absorb creative processes } \\
\text { and approaches }\end{array}$ & $\begin{array}{l}\text { Interpret local specificities } \\
\text { through international } \\
\text { lenses }\end{array}$ \\
\hline
\end{tabular}

Star-based Creative KIBS face the problem of the founders' time constraints; this means that in order to grow internationally they need to allocate the founders' time appropriately. The added value provided by star designers has to be distributed in the project portfolio through direct and indirect activities. While strategic projects benefit from the significant and direct contribution made by the founders, tactical projects make use of the individual talent exhibited by the founders in different solutions. Star-based Creative KIBS need to promote the designers' talent through exhibitions, books and so on. In other words, they make use of their human capital by exhibiting past results obtained by the stars. This category of creative KIBS is characterized by fast internationalization, but with a limited potential over the long run owing to the founders' time constraints. In fact, the individual success obtained by the stars allows the consultancies to quickly make contact with new foreign clients. The collaboration with Star-based Creative KIBS provides legitimacy to their clients and consequently is particularly appropriate for launching new product lines or proposing innovations in new markets.

Process-based Creative KIBS base their offering on collective design processes; this means that they need to embody the processes in order to demonstrate their validity and efficiency. While clients are reassured by the reputation of the individual designer in the case of Starbased Creative KIBS, Process-based Creative KIBS have to communicate and demonstrate the value of their creative processes. Several design agencies base their offering on specific methodologies and tools. This internationalization mode, based on organizational resources, is the one that was previously referred to for the famous American design consultancy IDEO (Brown, 2008). IDEO is presented as having strong and detailed processes: the capability to identify and analyze users' needs through applied ethnography. The embodiment of the design processes can be obtained by developing ad hoc tools able to support the interaction with clients and by formalizing the process. Design agencies belonging to the Process-based 
Creative KIBS category are characterized by progressive internationalization thanks to the ability to have an international niche positioning based on specialization. Clients of Processbased Creative KIBS have the opportunity to absorb new creative processes and approaches. Consequently, this category of collaborators is particularly appropriate for those clients that want to update their innovation processes.

Finally, Glocality-based Creative KIBS provide added value by interpreting local contexts and leveraging the experience accumulated by different offices. They need to tailor their approaches to suit local settings and provide the same level of service in all projects developed by different offices. They imbue design activities with local stories and cultural references. In order to guarantee consistency in the service provided by the international offices, they develop knowledge management systems that support the sharing of experiences and corporate values. Considering that communicative codes are very often culturally embedded, Glocality-based Creative KIBS tend to specialize in design services relating to brands and visual identity. This category of creative KIBS is characterized by slow internationalization, but with a high potential in the long run. It requires significant investment, but is based on long-lasting relationships with clients. Glocality-based Creative $K I B S$ are particularly appropriate for two categories of clients:

- international companies that are approaching new foreign markets where creative KIBS have already established foreign offices

- local companies that want to innovate their product/service offering through the interpretation of international creative KIBS

This paper enriches the literature on internationalization. It proposes a typology of internationalization modes for DC as a particular case of creative KIBS that is based on the resources leveraged by the firm in order to acquire a competitive position in an international context. This typology complements the typology found in the internationalization literature (Gemser et al., 2004; Kirby and Kaiser, 2003; Toivonen et al., 2009) that focuses mainly on market access whether it is direct (local investment), indirect (third party) or distant (export). Basing internationalization modes on resources is more consistent with the peculiarities of KIBS that are strongly associated with resources.

\section{CONCLUSIONS}

While the international development of manufacturing activities is based on economies of scale, firms operating in the service sector and specifically KIBS need alternative paths because of their knowledge intensity and of the importance of strong and close relationships with the client. This is especially true for creative KIBS such as design consultancies that rely on creative processes, both individual and collective. Specifically the paper investigates key resources on which creative KIBS base their competitiveness in internationalization. The paper suggests a new typology of internationalization modes focusing on the specific resources that can be used to develop international competitiveness: Star-based, Processbased and Glocality-based Creative KIBS. While the first two types leverage human capital and organizational capital, the third category leverages both physical and organizational resources. In this internationalization mode, companies develop direct relationships with clients located in several countries by setting up local offices. This allows them to interpret the local context and develop an intimate collaboration with local clients.

From a managerial perspective, the paper provides an interpretative model that creative KIBS can adopt to identify the appropriate mode for developing international activities according to the contingent variables they are facing and the key resources they already have. 
The proposed typology can also be used by policy makers that want to favor the development of domestic firms abroad in order to monitor and focus the help and incentives that could be given. For example policy makers can support different internationalization modes depending on the resources already developed by creative KIBS; in other words they can provide a sort of check-up service in order to analyze the potentialities of each company and then support the appropriate internationalization mode. The limitations of the research concern the limited static sample of a specific type of creative KIBS. For these findings to be generalized, they would first have to be tested on a larger sample across creative KIBS. Also, data on the failure of internationalization processes for this type of firm could be useful in providing recommendations. The design of the current study did not allow us to cull any insights about what leads to failure. This is a research limitation which could be addressed in future research. Finally future research could address the dynamic dimension of the topic by analyzing internationalization paths. 


\section{REFERENCES}

Abecassis-Moedas, C. and Ben Mahmoud-Jouini, S. (2008). Absorptive capacity and source-recipient complementarity in designing new products: an empirically derived framework. Journal of Product Innovation Management 25: 473-480.

Acs ZJ, Morck r, Shaver JM and Yeung B (1997). The Internationalisation of Small and Medium-Sized Enterprises: A Policy Perspective. Small Business Economics, Vol. 9, No. 1, Pp. 7-20.

Amabile TM (1988). A Model of Creativity and Innovation in Organizations. Research in Organizational Behavior, Vol. 10, Pp. 123-169.

Barney J (1991). Firm Resources and Sustained Competitive Advantage. Journal of Management, Vol. 17, No. 1, Pp. 99-120.

Bettiol M, Di Maria E and Grandinetti R (2011). The Determinants of Market Extension in Knowledge-Intensive Business Services: Evidence from a Regional Innovation System. DRUID 2011, June 15-17, Copenhagen, Denmark.

Brown T. (2008). Design thinking, Harvard Business Review (June), 84-92.

Buckley P J, Newbould GD and Thurwell JC (1988). Foreign Direct Investment by Smaller U.K. Firms; The Success and Failure of First-time Investors Abroad. London: Macmillan.

Chetty S and Campbell-Hunt C (2004). A strategic approach to internationalization: a traditional versus a "born global" approach. Journal of International Marketing, Vol. 12, No. 1, Pp. 57-81.

Chiaroni D, Chiesa V, De Massis A and Frattini F (2008). The knowledge bridging role of technical and scientific services in knowledge-intensive industries. International Journal of Technology Management, Vol. 41, No. 3/4, Pp. 249-272.

Colombo G, Dell'Era C and Frattini F (2011). New Product Development (NPD) service suppliers in Open Innovation practices: processes and organization for knowledge exchange and integration. International Journal of Innovation Management, vol. 15, No. 1, Pp. 165204.

Colombo, G., Dell'Era, C. and Frattini, F. (2012, forthcoming). How New Product Development (NPD) Service Suppliers Exchange Knowledge in Open Innovation Processes, in Brem, A. and Tidd, J. (eds.), Perspectives on Supplier Innovation, Imperial College Press, London

Corrocher N, Cusmano L and Morrison A (2009). Modes of innovation in knowledgeintensive business services evidence from Lombardy. Journal of Evolutionary Economics, Vol. 19, Pp. 173-196.

Czarnitzki D and Spielkamp A (2000). Business services in Germany: bridges for innovation. ZEW discussion paper, No. 00-52. Mannheim.

Dell'Era, C. and Verganti, R. (2007) Strategies of Innovation and Imitation of Product Languages. Journal of Product Innovation Management, 24, 580-99. 
Dell'Era C and Verganti R (2010). Collaborative strategies in design-intensive industries: Knowledge diversity and innovation. Long Range Planning, Vol. 43, Pp. 123-141.

Dell'Era C, Buganza T, Fecchio C and Verganti R (2011). Language Brokering: Stimulating Creativity during the Concept Development Phase. Creativity and Innovation Management, Vol. 20, No. 1, Pp. 36-48.

Doloureux D and Muller E (2007). The key dimensions of knowledge-intensive business services (KIBS) analysis. A decade of evolution. Working Paper Firms and Regions No. U1/2007, Fraunhofer-Institute fur System-und Innovationsforschung-ISI, Karlshrue.

Durgee JF (2006). Freedom of superstar designers? Lessons from art history. Design Management Review, Vol. 17, No. 3, Pp. 29-34.

Eden L, Levitas E and Martinez RJ (1997). The Production, Transfer and Spill-Over of Technology: Comparing Large and Small Multinationals as Technology Producers. Small Business Economics, Vol. 9, No. 1, Pp. 53-66.

Gemser G, Brand MJ and Sorge A (2004). Exploring the Internationalisation Process of Small Businesses: a Study of Dutch Old and New Economy Firms. Management International Review, Vol. 44, Issue 2, Pp. 127-150.

Gierke M; Hansen JG and Turner R (2002). Wise counsel: A trinity of perspectives on the business value of design. Design Management Journal, Vol. 13, No. 1, Pp. 10.

Hargadon AB (1998). Firms as knowledge brokers: lessons in pursuing continuous innovation. California Management Review, Vol. 40, No. 3, Pp. 209-227.

Hargadon AB (1999). Group Cognition and Creativity in Organizations. In Wageman R, Neale MA and Mannix B (Eds.). Groups in Context, v2: 137-155.

Hargadon AB (2003). Retooling R\&D: Technology brokering and the pursuit of innovation. Ivey Business Journal. Vol.68, 2, Pp.1-7.

Hargadon AB and Bechky BA (2006). When Collections of Creatives Become Creative Collectives: A Field Study of Problem Solving at Work. Organization Science, Vol. 17, No. 4, Pp. 484-500.

Hargadon AB and Sutton RI (1997). Technology brokering and innovation in a product development firm. Administrative Science Quarterly, Vol. 42, No. 4, Pp. 716-749.

den Hertog P (2000). Knowledge intensive business services as co-producers of innovation. International Journal of Innovation Management, Vol. 4, NBo. 4, Pp. 491-528.

Hill R and Johnson LW (2003). When Creativity is a Must: Professional "Applied Creative" Services. Creativity and Innovation Management, Vol. 12, No. 4, Vol. 221-229.

Hipp C. Information flows and knowledge creation in knowledge-intensive business services: scheme for a conceptualization, in J.S. Metcalfe and I. Miles (Eds.) Innovation Systems in the Service Economy, (2000) Boston: Kluwer Academic Publishers

Katsoulacos, Y. and Tsounis, N. (2000) Knowledge-Intensive Business Services and productivity growth: the Greek evidence, in Boden, M. and Miles, I., (eds), Services and the Knowledge-Based Economy, London: Continuum.

Kirby DA and Kaiser S (2003). Joint Ventures as an Internationalisation Strategy for SMEs. Small Business Economics, Vol. 21, Pp. 229-242. 
Koschatzky K and Zenker A (1999). The Regional Embeddedness of Small Manufacturing and Services Firms: Regional Networking as Knowledge Source for Information? Working Paper, Institute Systems and Innovation Research.

Miles, M. B. and Huberman, A. M. (1994). Qualitative Data Analysis: an expanded sourcebook, Sage, Thousand Oaks, CA.

Miles I (2005). Knowledge intensive business services: prospects and policies. Foresight, Vol. 7, No. 6, Pp. 39-63.

Miles I (2007). Research and development (R\&D) beyond manufacturing: the strange case of services R\&D. R\&D Management, Vol. 37, No. 3, Pp. 249-268.

Morris T and Empson L (1998). Organisation and expertise: an exploration of knowledge bases and the management of accounting and consulting firms. Accounting, Organization and Society, Vol. 23, No. 5/6, Pp. 609-662.

Muller E and Zenker A (2001). Business services as actors of knowledge transformation: the role of KIBS in regional and national innovation system. Research Policy, Vol. 30, Pp. 1501-1516.

Muller E (2001) Innovation interactions between Knowledge-Intensive Business Services and Small-and Medium-sized Enterprises: an analysis in terms of evolution, knowledge and territories, Heidelberg: Physica-Verlag.

NSF, Science and Engineering Indicators 2010.

Oke A (2007). Innovation types and innovation management practices in service companies. International Journal of Operations \& Production Management, Vol. 27, No. 6, Pp. 564-587.

Paige R.C. and Littrel M.A. 2002 Craft retailers' criteria for success and associated business strategies Journal of small Business Management, 40(4): 314-332

Ravasi, D. and Lojacono, G. 2005 ' Managing Design and Designers for Strategic Renewal.' Long Range Planning, 38, Pp. 51-77

Rindova, V.P. \& Petkova, A.P. (2007), 'When Is a New Thing a Good Thing? Technological Change, Product Form Design, and Perceptions of Value for Product Innovations.' Organization Science 18(2), Pp. 217-232

Roberts J (1998). Multinational Business Service Firms: The Development of Multinational Organizational Structures in the UK Business Services Sector. Ashgate, Aldershot.

Sirilli G and Evangelista R (1998). Technological innovation in services and manufacturing: results from Italian surveys. Research Policy, Vol. 27, Pp. 881-899.

Sondheimer JA and Bargas SE (1993). US International Sales and Purchases of Private Services. Survey of Current Business, Vol. 73, No. 9, Pp. 120-156.

Starbuck S (1992). Learning by Knowledge-Intensive Firms. Journal of Management Studies, Vol. 29, No. 6.

Sutton RI (2002). Weird Ideas that Spark Innovation: Counterintuitive approaches are helping companies keep their creative edge. MIT Sloan Management Review, Vol.43, $\mathrm{N}^{\circ} 2$, Pp.83-87.

Tether BS, Hipp C and Miles I (2001). Standardisation and particularisation in services: Evidence from Germany. Research Policy, Vol. 30, No. 7, Pp. 1115-1138. 
Toivonen M (2004). Expertise as business: long-term development and future prospects of knowledge-intensive business services. Doctoral Dissertation Series, Helsinki University of Technology. Available at: http://lib.tkk.fi/Diss/2004/isbn9512273152/

Toivonen M, Tuominen T, Smedlund A and Patala I (2009). Models and paths of internationalisation in KIBS. 29th International RESER Conference, September 24-26, Budapest, Hungary.

Ulrich KT and Eppinger SD (2011). Product Design and Development. McGraw Hill.

Vandermerwe S and Chadwick M (1989). The internationalisation of services. The Service Industries Journal, Vol. 9, No. 1, Pp. 79-93.

Verganti, R. (2006) Innovating through Design. Harvard Business Review, 84, 114-22.

Verganti, R. (2008). Design, Meanings, and Radical Innovation: A Metamodel and a Research Agenda. Journal of Product Innovation Management, Vol. 25, Pp. 434-456.

Verganti, R. (2009) Design Driven Innovation - Changing the Rules of Competition by Radically Innovating what Things Mean. Harvard Business Press, Boston, MA.

Wernerfelt B (1984). A Resource-Based view of the Firm. Strategic Management Journal; Vol. 5, No. 2, Pp. 171-180.

Werr A and Stjernberg T (2003). Exploring Management Consulting Firms as Knowledge Systems. Organization Studies, Vol. 24, No. 6, Pp. 881-908.

Windrum $\mathrm{P}$ and Tomlinson M (1999). Knowledge-intensive services and international competitiveness: a four country comparison, Technology Analysis \& Strategic Management, Vol. 11, No. 3, Pp. 391-405.

Wood PA, Byson J and Keeble D (1993). Regional patterns of small firm development in the business services: evidence from the UK. Environ Plan A 25, Pp. 667-700. 